\title{
Development of materials for environmental pollution control from cocoa pod shells
}

\author{
David Léonce KOUADIO, Adjoavi Colette DJASSOU, Akissi Lydie Chantal KOFFI, Karim Sory \\ TRAORE
}

\begin{abstract}
To eliminate pollutants efficiently and at a lower cost, research is focused on the use of agricultural waste as a pollution control material. This work involves the analysis of the physical and chemical parameters of raw carbon from cocoa pod shells. The cocoa shells were crushed using Retsch SK100 brand shredders and sieved from Retsch type sieves to retain only particles with diameters between $0.5 \mathrm{~mm}$ and $1 \mathrm{~mm}$. Pyrolysis was carried out at $400^{\circ}, 450^{\circ}, 500^{\circ}$ and $550^{\circ} \mathrm{C}$ in a Nabatherm $30-3300^{\circ} \mathrm{C}$ muffle furnace. Analysis of the results indicates pyrolysis yields of less than $50 \%$ and ash rates varying from $15 \%$ to $17.2 \%$. The porosity study showed that carbons developed a heterogeneous porosity with maximum iodine and methylene blue index values equal to $659 \mathrm{mg} / \mathrm{g}$ and $104.56 \mathrm{mg} / \mathrm{g}$ respectively and a specific area varying from $427.75 \mathrm{~m}^{2} / \mathrm{g}$ to $588.25 \mathrm{~m}^{2} / \mathrm{g}$. These physical characteristics allowed to determine the best raw carbons. The modeling of the basic and acid dye adsorption kinetics follows the intra-particle diffusion model. The equilibrium time obtained is $60 \mathrm{~min}$.
\end{abstract}

Index Terms - Terms-adsorption, cocoa pod, depollution, raw carbon.

\section{INTRODUCTION}

Environmental pollution is identified as one of the most serious environmental problems today [1]. Environmental pollutants of all kinds contaminate water, air and soil, endangering living things [2]. In Côte d'Ivoire, traces of heavy metals and pesticides have been found in fish from the Ebrié lagoon [3]. The work of [4] showed that the breast milk of women in the buyo area contains organochlorine pesticide residues. According to the World Health Organization (WHO), $24 \%$ of current diseases in the world can be attributed to environmental pollution [5]. Faced with this worrying pollution, environmental clean-up appears to be a major global challenge to be met in order to avoid the degradation of ecological balances and protect human health.

In recent years, many techniques have been developed to remove pollutants from water, air and soil. Among these techniques, the carbon adsorption technique is the most widely used [6]. However, commercial activated carbons, the main adsorbents used, are relatively expensive, which limits their use in developing countries. Thus, in recent decades, the

David Léonce KOUADIO, Laboratory for Environmental Science and Technology, Jean Lorougnon GUEDE University, Daloa, Côte d'Ivoire, +2253232787583 .

Adjoavi Colette DJASSOU, Laboratory for Environmental Science and Technology, Jean Lorougnon GUEDE University, Daloa, Côte d'Ivoire, +2253232787583 .

Akissi Lydie Chantal KOFFI, Laboratory for Environmental Science and Technology, Jean Lorougnon GUEDE University, Daloa, Côte d'Ivoire, +2253232787583 .

Karim Sory TRAORE, Laboratory of Environmental sciences, Nangui ABROGOUA Universsity, Abidjan, Côte d'Ivoire, +22520304200. search for cheap adsorbent materials with comparable efficiency to commercial activated carbons in their use has been an important research theme [7].

It is in this context that this research study is part of which aims to evaluate the adsorption performance of carbon from cocoa pod shells. In Côte d'Ivoire, annual production of cocoa beans ranges from 1,500,000 to 1,700,000 tonnes. From this production comes about 13 to 15 million tonnes of cocoa residues. Thus, cocoa pod shells are widely available agricultural by-products that can be used as raw material for the manufacture of high-performance coals. Specifically, it is:

(a) Prepare and characterize raw coal

(b) Determine the optimal condition for the preparation of raw coal

(c) Investigate the adsorption capacity of optimal carbon on organic pollutants.

\section{METHODS}

\section{A. Preparation of coals}

The cocoa shells were washed and dried for a week under air conditioning at $18^{\circ} \mathrm{C}$ (dehydration) and in an oven at $60^{\circ} \mathrm{C}$. At the exit of the oven the pod shells were crushed manually and crushed by a Retsch SK 100 crusher. The resulting shred was sieved from Retsch sieves with diameters of $1 \mathrm{~mm}$ and 0.5 $\mathrm{mm}$, retaining only those of a size between these two diameters.

The preparation of the coals was done in a single step: carbonization. The mashes were impregnated in distilled water for 24 hours followed by pyrolysis at $400^{\circ} \mathrm{C}, 450^{\circ} \mathrm{C}$, $500^{\circ} \mathrm{C}$ and $550^{\circ} \mathrm{C}$ with respective heating rates of $10^{\circ} \mathrm{C} / \mathrm{min}$, $11.35^{\circ} \mathrm{C} / \mathrm{min}, 12.70^{\circ} \mathrm{C} / \mathrm{min}$ and $14.05^{\circ} \mathrm{C} / \mathrm{min}$, a 3 -hour isothermal bearing in a muffle furnace (NABATHERM $30-3000^{\circ} \mathrm{C}$ ). After calcination, the coals obtained were cooled and rinsed several times with distilled water and then dried in an oven at $105^{\circ} \mathrm{C}$ for 24 hours.

i. Characterization of coals

In this study, the yield, ash content, porosity, specific surface area and surface function were determined.

\section{B. Characterization of coals}

- Yield

The yield reflects the loss of biomass mass during carbonization. It is the ratio between the mass of coal obtained and the mass of biomass used. yield $(\%)=\frac{\text { masse }_{\text {charbon }}}{\text { masse }_{\text {biomass }}} \times 100$

- Ash rate

This is the inorganic, unusable part present in coal. This rate was determined by the method described by [8]. A sample of $0.5 \mathrm{~g}\left(\mathrm{~m} \_1\right)$ of coal is placed in a crucible ( $\left.\mathrm{m} \_2\right)$. This crucible is introduced into a muffle furnace set at $650^{\circ} \mathrm{C}$ for 2 hours 
At the exit of the furnace, the crucible is cooled to room temperature. The crucible is weighed again (m_3). The ash rate is determined as follows: $C(\%)=\frac{\left(m_{3}-m_{2}\right)}{m_{1}} \times 100$.

- Iodine index

The purpose of the iodine index test is to determine the ability of carbon to adsorb small molecules. This test was carried out according to AWWA B 600-78 from the work of [9]. In a $100 \mathrm{~mL}$ beaker, $0.05 \mathrm{~g}$ of coal is introduced. $20 \mathrm{~mL}$ of $0.1 \mathrm{~N}$ iodine solution is added to the $20 \mathrm{~mL}$ pipette and the mixture is stirred for 5 minutes before filtering. A volume of $10 \mathrm{~mL}$ of the filtrate is taken and placed in an Erlenmeyer. From the burette, a sodium thiosulphate solution of $0.1 \mathrm{~N}$ concentration is added to the Erlenmeyer containing the filtrate until the solution is completely discoloured. Starch poison is used as a coloured indicator. The iodine index is given by the following formula: Iodine index $(\mathrm{mg} / \mathrm{g})=\frac{\left(\mathrm{C}_{\mathrm{o}}-\frac{\mathrm{C}_{\text {shio }} V_{\text {chiog }}}{2 V_{I 2}}\right) M_{I 2} V_{a d s}}{\mathrm{~m}_{\mathrm{r}}}$ $\mathrm{C}_{\mathrm{o}}$ : Initial concentration of iodine solution ( $\mathrm{mol} / \mathrm{L}$ )

$\mathrm{C}_{\text {thio }}$ : Concentration of sodium thiosulphate solution (mol/L) $\mathrm{V}_{\text {thio }}$ : Volume of thiosulfate poured at the equivalent level (mL)

$\mathrm{V}_{\mathrm{I} 2}$ : Quantity of iodine measured $(\mathrm{mL})$

$\mathrm{M}_{\mathrm{I} 2}$ : Molar mass of iodine $(\mathrm{g} / \mathrm{mol})$

$\mathrm{V}_{\mathrm{ads}}$ : Adsorption volume $(\mathrm{mL})$

$\mathrm{m}_{\mathrm{c}}$ : Mass of coal $(\mathrm{g})$.

- Methylene blue index

The methylene blue index $(\mathrm{mg} / \mathrm{g})$ is an indicator of the ability of carbon to adsorb medium and large organic molecules. It characterizes the meso pores of coal. For the determination of this index, the method of the European Chemical Industry Federations Centre (CEFIC, 1989), based on the work of [10], was used. In a $250 \mathrm{~mL}$ Erlenmeyer, $0.1 \mathrm{~g}$ of carbon and 100 $\mathrm{mL}$ of 1.944.10-5 M methylene blue solution are introduced. The mixture is stirred for 20 minutes and then filtered. The residual concentration of methylene blue is determined using a UV-Visible spectrophotometer at a wavelength of $620 \mathrm{~nm}$. Thus, the methylene blue index is given by the following relationship: Methylene blue index $(\mathrm{mg} / \mathrm{g})=\frac{\text { VMx }\left(C_{\mathrm{i}}-C_{\mathrm{T}}\right)}{m_{r}}$ with

$\mathrm{V}$ : Volume of methylene blue solution in $(\mathrm{mL})$

$\mathrm{M}$ : Molar mass of methylene blue $(\mathrm{g} / \mathrm{mol})$

$\mathrm{C}_{\mathrm{i}}$ : Initial concentration of methylene blue in $(\mathrm{mol} / \mathrm{L})$

$\mathrm{C}_{\mathrm{r}}$ : Residual concentration of methylene blue in $(\mathrm{mol} / \mathrm{L})$

$\mathrm{m}_{\mathrm{c}}$ : Mass of coal $(\mathrm{g})$.

- Specific surface area

The specific surface area was determined by the methylene blue adsorption method described by [11]. $100 \mathrm{~mL}$ of 6.25.10-6M methylene blue solution are contacted with $0.1 \mathrm{~g}$ of coal. The suspension is shaken for $60 \mathrm{~min}$ at $10 \mathrm{~min}$ intervals. Residual concentrations were determined by spectrophotometric assay at $665 \mathrm{~nm}$. The determination of the maximum adsorption capacity is done by applying the Langmuir model to the adsorption isotherms of methylene blue on coals. From the maximum adsorption capacity $Q_{m}$, the specific surface area is determined by the following equation: $S_{L}=Q_{m} * N_{A} * S_{B M}$ With

$S_{L}:$ Specific surface area of Langmuir $\left(\mathrm{m}^{2} / \mathrm{g}\right)$

$Q_{m}$ : Maximum adsorption capacity $(\mathrm{mg} / \mathrm{g})$

$N_{A}$ : Avogadro number (6,022.1023mol-1)

$S_{B M}$ : Surface occupied by a molecule of methylene blue $(175.10-20 \mathrm{~m} 2)$ ii. Evaluation of the adsorption capacity of optimal carbon: kinetics and adsorption rate of blue 16 and methyl red dyestuffs

Adsorption was performed as a function of time to determine the amount of dye adsorbed at different time intervals and the equilibrium time. $0.1 \mathrm{~g}$ of carbon was contacted with $50 \mathrm{ml}$ of 16 blue solution of $6.10-4 \mathrm{~mol} / \mathrm{L}$ concentration and red methyl concentration $1.85 .10-4 \mathrm{~mol} / \mathrm{L}$. The mixture is stirred at times ranging from 10 to $90 \mathrm{~min}$ at $10 \mathrm{~min}$ intervals. The amount of dye adsorbed during the experiments is given by the following relationship: $Q_{\mathrm{t}}=\frac{\left(c_{\mathrm{i}}-c_{\mathrm{r}}\right) \cdot V}{\mathrm{~m}}$ With

$Q_{t}$ : Quantity of dye adsorbed $(\mathrm{mg} / \mathrm{g})$

$C_{\hat{i}}$ : Initial dye concentration $(\mathrm{mg} / \mathrm{L})$

$C_{Y}$ : Residual dye concentration at time $\mathrm{t}(\mathrm{mg} / \mathrm{L})$

$V$ : Volume of the dye solution (L)

$m$ : Mass of coal (g)

The dye adsorption rates were determined by the following formula : adsorption rate $(\%)=\frac{\left.\llbracket c_{\mathrm{i}}-c_{\mathrm{T}}\right\} * 100}{c_{\mathrm{i}}}$

Table I: Characteristics of blue 16 and red methyl

\begin{tabular}{|l|l|l|}
\hline Nom usuel & Blue 16 dye & Red methyl dye \\
\hline $\begin{array}{l}\text { Chemical } \\
\text { structure }\end{array}$ \\
\hline $\begin{array}{l}\text { Chemical } \\
\text { formula }\end{array}$ & $\mathrm{C}_{20} \mathrm{H}_{13} \mathrm{~N}_{2} \mathrm{NaO}_{5} \mathrm{~S}$ & $\mathrm{C}_{15} \mathrm{H}_{15} \mathrm{~N}_{3} \mathrm{O}_{2}$ \\
\hline Molar mass & $416,38 \mathrm{~g} / \mathrm{mol}$ & $269,31 \mathrm{~g} / \mathrm{mol}$ \\
\hline $\begin{array}{l}\text { Solubility in } \\
\text { water }\end{array}$ & $20 \mathrm{~g} / \mathrm{L}$ & $0,1 \mathrm{~g} / \mathrm{L}$ \\
\hline $\begin{array}{l}\text { Max } \\
\text { wavelength }\end{array}$ & $589 \mathrm{~nm}$ & $523-526 \mathrm{~nm}$ \\
\hline \begin{tabular}{l}
$\mathrm{pH}$ \\
\hline
\end{tabular} & 9,4 & $4,4-6,0$ \\
\hline
\end{tabular}

\section{RESULTATS AND DICUSSION}

Four coal samples were characterized. Carbonized coals at $400^{\circ} \mathrm{C}(\mathrm{CB} 400), 450^{\circ} \mathrm{C}(\mathrm{CB} 450), 500^{\circ} \mathrm{C}(\mathrm{CB} 500)$ and $550^{\circ} \mathrm{C}$ (CB550).

\section{A. Yield and ash rate}

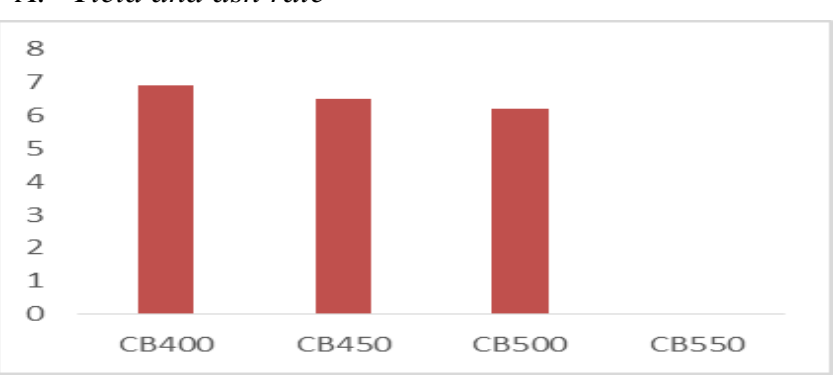

Fig.1: Yield of coals

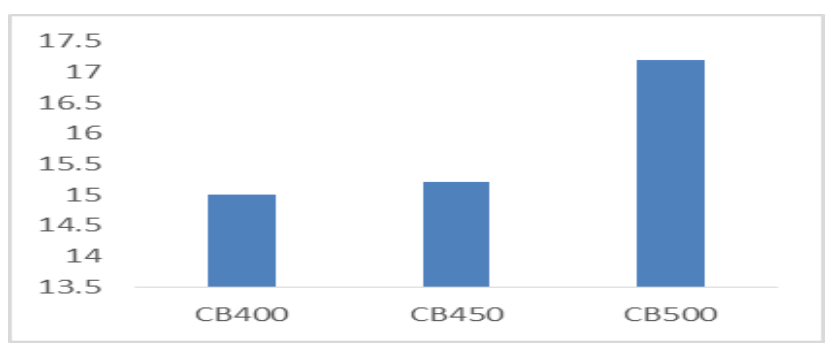

Fig.2: Ash rate of coals 
The results of yields and ash rates, expressed as a percentage by mass, are shown in Figures 1 and 2 respectively. According to [12], the carbonization temperature has a large influence on the mass efficiency. This explains the enormous loss of volatile matter under the effect of temperature (Fig. 1). Indeed, we notice a loss of more than $90 \%$ of the biomass mass between $400^{\circ} \mathrm{C}$ and $500^{\circ} \mathrm{C}$ when passing from the cocoa pod shell to raw coal. And, we also note $100 \%$ loss of biomass mass at $550^{\circ} \mathrm{C}$. All this could be explained by the fact that the higher the temperatures, the more the macromolecules that make up biomass are degraded into volatile matter [13]. For example, [13] was able to highlight this by preparing activated carbon from medlar fruit stones. It can also be seen that between 400 and $500^{\circ} \mathrm{C}$, the mass efficiency has changed very little, which would be due to the stability of the coal formed at these temperatures [12]. Figure 2 shows an increase in the ash rate as the temperature increases. However, we notice that there is not enough difference between the ash rate at $400^{\circ} \mathrm{C}$ and $450^{\circ} \mathrm{C}$. These different ash rate values are all greater than or equal to $15 \%$, the maximum tolerable value for an activated carbon [14]. Of the three coals obtained, CB400 and CB450 because of their lower ash content than CB500 would give a higher microporous volume [15]. The results obtained are in agreement with those of [15]. Indeed, in his study on raw coals from olive pits, [15] observed a variation in ash content from $0.8 \%$ to $2.3 \%$ for carbonization temperatures ranging from $400^{\circ} \mathrm{C}$ to $900^{\circ} \mathrm{C}$.

\section{A. Study of porosity: Microporosity and Mesoporosity}

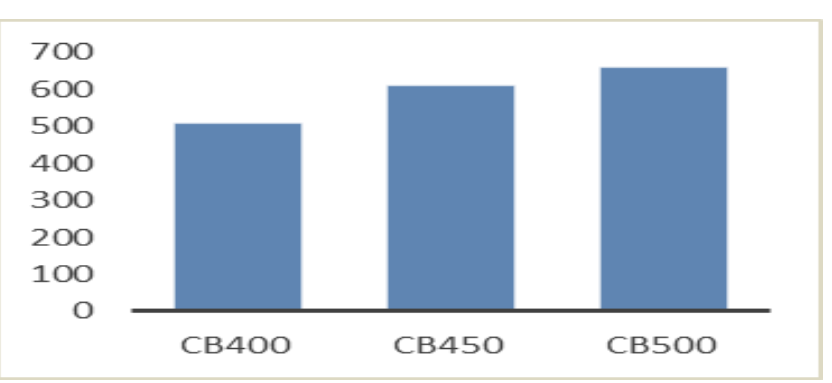

Fig. 3: Iodine index of coals

120
100
80
60
40
20

0

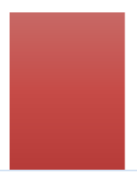

CB400

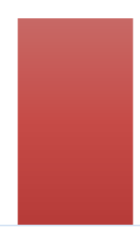

CB450

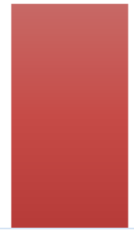

CB500
Fig. 4: Methylene blue index of coals

When the temperature is changed from $400^{\circ}$ to $500^{\circ} \mathrm{C}$, the iodine index increases from 507 to $659 \mathrm{mg} / \mathrm{g}$ (Fig. 3). Indeed, the increase in temperature favours the appearance of new micropores leading to an increase in the adsorption capacity of carbon and therefore in the iodine index [16]. The iodine index values obtained are comparable to those obtained by [17] on activated olive and apricot stones $(571 \mathrm{mg} / \mathrm{g}$; $533 \mathrm{mg} / \mathrm{g}$ ). However, [12] noted that above a certain temperature, the iodine index decreases with increasing temperature. This could be explained by the destruction of some of the micropores formed [18],[19]. And this significant reduction in the number of micropores is accompanied by a significant decrease in charcoal adsorption capacity [12]. The methylene blue indices obtained range from 73.54 to $104.54 \mathrm{mg} / \mathrm{g}$ (Fig. 4). These values are relatively low compared to those of iodine indices. However, they evolve in the same way. Indeed, the methylene blue index increases as the temperature increases. This evolution was also observed by [13] during the adsorption of methylene blue by activated carbons from medulla nuclei at temperatures ranging from 450 to $650^{\circ} \mathrm{C}$. For this author, this evolution of the methylene blue index may be due to the increase in the volume of mesopores with temperature [13]. Thus, as [9], we note that the coals that have developed the best iodine indices are those that have the best methylene blue indices. Hence, there is a positive correlation between the two indices (Fig. 5)

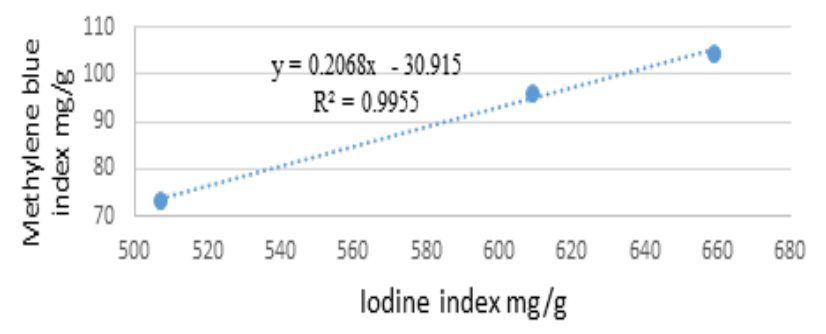

Fig. 5: Correlation between iodine index and methylene blue index of coals

B. Specific surface area

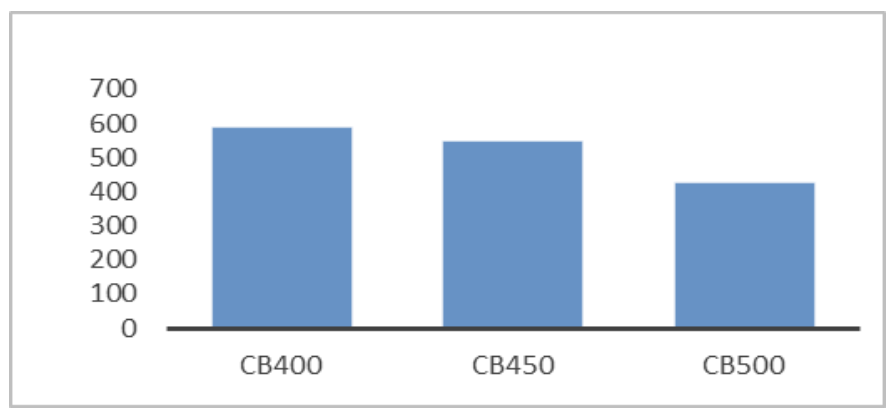

Fig. 6: Specific surface area of coals

The results obtained show a decrease in the specific surface area with the increase in temperature (Fig. 6). By increasing the temperature from 400 to $500^{\circ} \mathrm{C}$, the specific surface area decreases from 588.25 to $427.75 \mathrm{~m}^{2} / \mathrm{g}$. These results are not consistent with the results obtained by a number of researchers [20],[10]. For example, [10], moving from a temperature of 400 to $600^{\circ} \mathrm{C}$ with activated carbon obtained from Balanites Eagyptiaca nuclei shells impregnated with 5\% $\mathrm{H} 3 \mathrm{PO} 4$, noted that the specific surface area increased from 710.66 to $837.57 \mathrm{~m} 2 / \mathrm{g}$. Moreover, [21] point out that specific surfaces increase with increasing temperature. As for the results obtained during this study, they would be due to the chemical composition of the biomass. However, there is a correlation between iodine and methylene blue indices with specific surface area (Fig. 7 and 8).

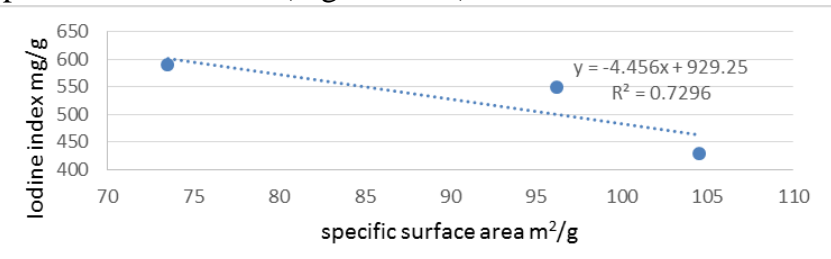

Fig. 7: Correlation between iodine index and specific surface area of coals 


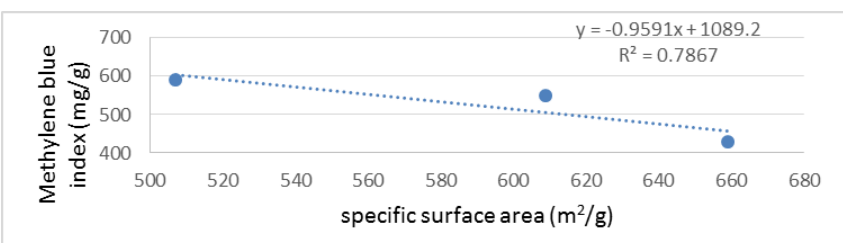

Fig. 8: Correlation between methylene blue index and specific surface area of coals

C.Evaluation of the adsorption capacity of blue 16 and methyl red dyestuffs by optimal raw coal

For adsorption kinetics, only carbonized raw coals at $450^{\circ} \mathrm{C}$ were used. Indeed, at this temperature, we obtained coals with an ash content very close to that of CB400 but with a better porosity than the latter. In addition, the temperature of $450^{\circ} \mathrm{C}$ has a better influence on pyrolysis [12].

The adsorption kinetics curves of the CB450 blue 16 and methyl red dyes are shown in Fig. 9 and 10 respectively.

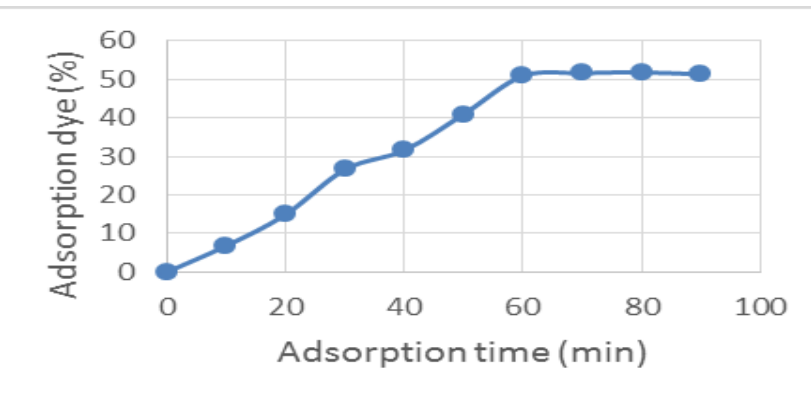

Fig. 9: Kinetics of adsorption of blue 16

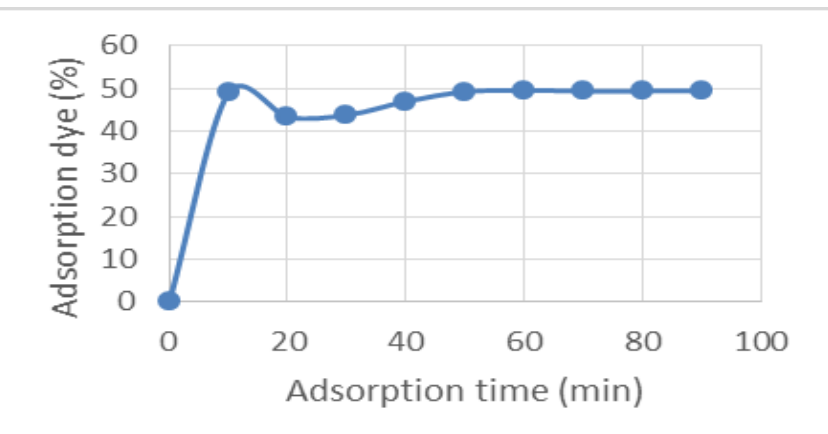

Fig. 10: Kinetics of adsorption of red methyl

The red methyl adsorption curve has three phases. A first phase of rapid adsorption from 0 to $20 \mathrm{~min}$. This phase is followed by a slow adsorption phase before reaching the equilibrium phase. For the adsorption of blue 16, the curve has two phases. This would be related to the intraparticle diffusion of adsorbate molecules into the pores of the carbon. Indeed, according to [17], the intraparticle diffusion process takes place in two phases. A first phase which represents the diffusion of the molecules in the coals and a second phase representing the adsorption equilibrium. The first step is the longest step. For both dyes, the equilibrium is reached at $60 \mathrm{~min}$. We notice that the maximum adsorption rate of the blue dye $16(51.85 \%)$, basic dye is higher than that of the red methyl dye $(49.62 \%)$, acid dye. These results are consistent with those of [17]. Indeed, this author has shown that the adsorption capacities of basic dyes are higher than those of acid dyes on the same adsorbent. Also, [22], in studying the adsorption of acid blue and basic yellow dye on coffee pomace, observed better adsorption in basic yellow dye. It is also noted that red methyl adsorption is faster than blue 16 . This could be related to the molecular weight of the adsorbate. Indeed, some researchers have shown that the higher the molecular weight, the slower the adsorption [23]. And red methyl has a molecular weight about half as small as that of blue 16 .

\section{MODELING OF DYE ADSORPTION KINETICS}

The graphical representations of the pseudo-first order, pseudo-second order and intraparticle diffusion equations of dye adsorption are given in Fig. 11, 12 and 13 respectively.

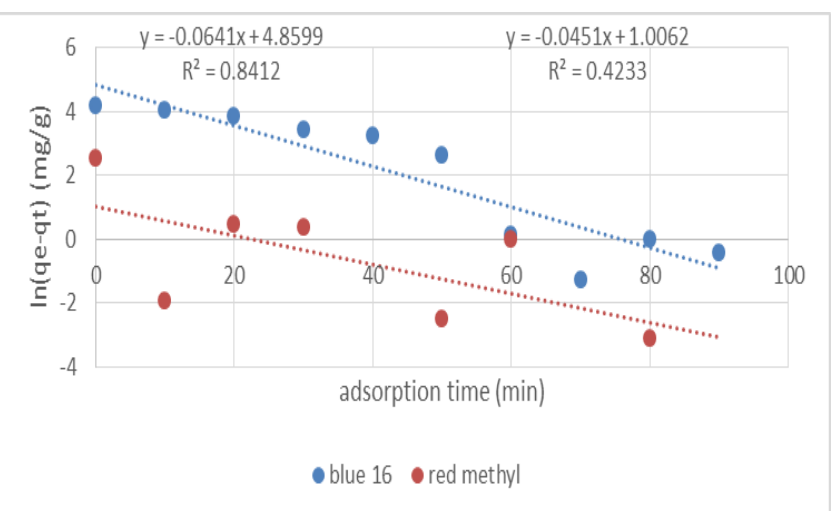

Fig. 11 : Pseudo-first order model of dyes adsorption kinetics

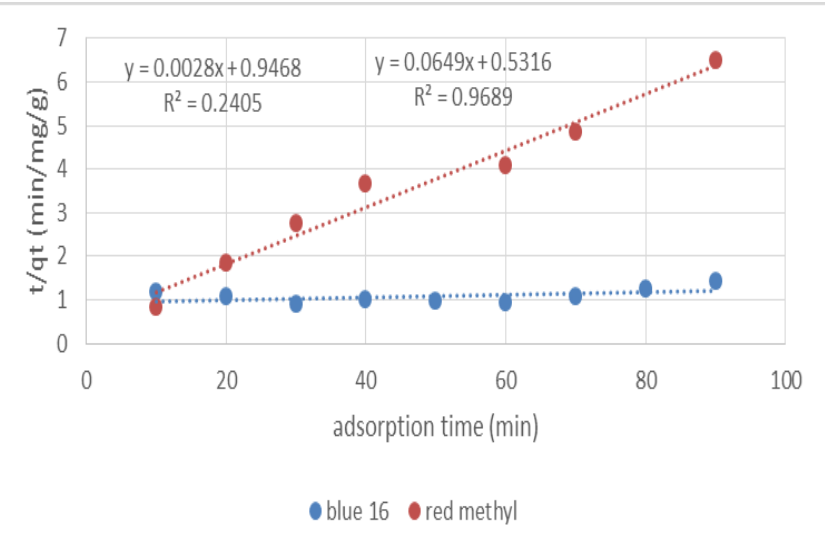

Fig. 12 : Pseudo-second order model of dyes adsorption kinetics

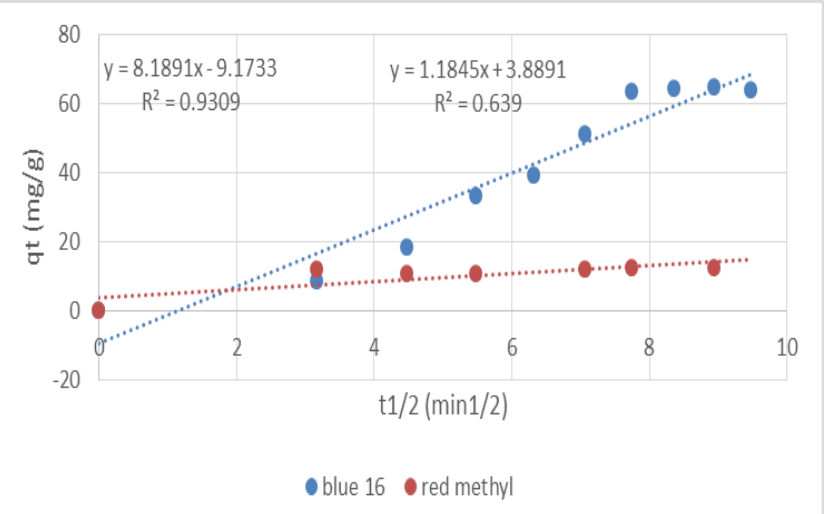

Fig. 13: Model of intraparticular diffusion of adsorption kinetics of dyes

The different parameters of the graphical representations of the pseudo-first, pseudo-second order and intraparticle diffusion equations are summarized in Table II. 
Table II : Paramètres de la cinétique d'adsorption des colorants bleu 16 et méthyle rouge.

\begin{tabular}{|c|c|c|c|c|}
\hline Model & \multicolumn{4}{|c|}{ Pseudo-first order } \\
\hline $\begin{array}{l}\text { Kinetics } \\
\text { paramete }\end{array}$ & $\mathrm{K}_{1}\left(\min ^{-1}\right)$ & $\begin{array}{l}\mathrm{q}_{\mathrm{e}} \text { (cal) } \\
(\mathrm{mg} / \mathrm{g})\end{array}$ & $\begin{array}{l}\mathrm{q}_{\mathrm{e}} \quad(\exp ) \\
(\mathrm{mg} / \mathrm{g})\end{array}$ & $\mathrm{R}^{2}$ \\
\hline Blue 16 & 0,0641 & 129,01 & 64,8 & 0,8412 \\
\hline Red methyl & 0,0451 & 2,73 & 12,36 & 0,4233 \\
\hline Model & \multicolumn{4}{|c|}{ Pseudo-second order } \\
\hline & $\begin{array}{l}\mathrm{K}_{2} \\
(\mathrm{~g} / \mathrm{mg} \cdot \min )\end{array}$ & $\begin{array}{l}\mathrm{q}_{\mathrm{e}} \text { (cal) } \\
(\mathrm{mg} / \mathrm{g})\end{array}$ & $\begin{array}{l}\mathrm{q}_{\mathrm{e}} \quad(\exp ) \\
(\mathrm{mg} / \mathrm{g})\end{array}$ & $\mathrm{R}^{2}$ \\
\hline Blue 16 & 0,0029 & 18,89 & 64,8 & 0,2405 \\
\hline Red methyl & 0,122 & 3,92 & 12,36 & 0,9689 \\
\hline Model & \multicolumn{4}{|c|}{ Intraparticular diffusion } \\
\hline Kinetics & $\begin{array}{l}\mathrm{K}_{\mathrm{d}} \\
\left(\mathrm{mg} / \mathrm{g} \cdot \min ^{1 / 2}\right)\end{array}$ & $\begin{array}{l}\mathrm{q}_{\mathrm{e}} \text { (cal) } \\
(\mathrm{mg} / \mathrm{g})\end{array}$ & $\begin{array}{l}\mathrm{q}_{\mathrm{e}} \quad(\exp ) \\
(\mathrm{mg} / \mathrm{g})\end{array}$ & $\mathrm{R}^{2}$ \\
\hline Blue 16 & 8,1891 & 64,07 & 64,8 & 0,9309 \\
\hline Red methyl & 1,1845 & 13,06 & 12,36 & 0,639 \\
\hline
\end{tabular}

Analysis of the results shows that for red methyl dye, the correlation coefficient of the linear representation of the pseudo-second order equation is higher than that of the pseudo-first order and intraparticle diffusion. For the basic blue 16 dye, the correlation coefficient of the intraparticle diffusion model is higher than that of the other two models. Thus, one could think that the retention of red methyl dye by CB450 coals could be represented by second-order kinetics. The results would be similar to those obtained by other authors such as [24], [7] and [14].

Thus, this should support the so-called de [25], according to which the kinetic data of acid dye adsorption on agricultural waste generally follows the pseudo-second order model. However, the estimated values of qe (cal), by the pseudo-first and pseudo-second order kinetic models, gave different values with a fairly large deviation from the experimental values. For the intraparticle diffusion model, these values are very close to the experimental values regardless of the dye. Thus, the comparison of the results of qe (cal) and qe (exp) indicates that the model that best reproduces the experimental data is the intraparticle diffusion model [26]. This implies that adsorptions are determined by the intraparticle diffusion of solute molecules through macropores, mesopores and micropores [14].

\section{CONCLUSION}

This study evaluates the adsorption performance of raw carbon from cocoa pod shells. The results obtained indicate that the optimal carbonization temperature for coal preparation is $450^{\circ} \mathrm{C}$. At this temperature, the coals have an ash content of $15.2 \%$, an efficiency of $6.5 \%$, iodine and methylene blue indices at $609 \mathrm{mg} / \mathrm{g}$ and $96.25 \mathrm{mg} / \mathrm{g}$ respectively, and a specific surface area of $548.95 \mathrm{~m}^{2} / \mathrm{g}$. The adsorption kinetics on optimal carbon indicates that equilibrium times are reached at $60 \mathrm{~min}$ with maximum adsorption rates of $51.85 \%$ for blue dye 16 and $49.62 \%$ for red methyl dye. Linear regressions and comparison of the results of qe (cal) and qe (exp) showed that the kinetics of adsorption of acid and basic dyes by optimal raw coal are controlled by the intraparticle diffusion model.

\section{REFERENCES}

[1] P. Failler. (2015). Evaluation de la pollution de l'environnement et de son impact sur les initiatives de cooperation économique et d'intégration régionale, rapport national, Djibouti. pp. 37.

[2] A. Maamri. (2017). Impact de l'environnement sur la santé humaine. Annale des sciences de la santé. 10 (1). pp. 1-8.

[3] A.A. Adingra and A.M. Kouassi. (2011). Pollution en lagune Ebrié et ses impacts sur l'environnement et les populations riveraines. Marine pollution bulletin. 36 . pp. 48-53.

[4] S.K. Traoré, M. Koné, A. Dembele, P. LaFrance, O. Banton and P. Houenou. (2002). Résidus de pesticides organochlorés dans le lait humain d'une zone agricole de Côte d'Ivoire. Journal de la Société Ouest-africaine de Chimie. 13. pp. 99-109.

[5] A. Maamri. (2016). Cancer au Maroc oriental : changements climatiques et facteurs de risque. COP22, Marakech, Maroc, 7-18 Novembre.

[6] A.F. Kokora, D.L. Kouadio, D.B. Soro, K.R. N'Guettia, A. Dembele and S.K. Traoré. (2018). Elimination d'un colorant textile sur des adsorbants issus de déchets agricoles. Revue Ivoirienne des Sciences et Technologies. 31. pp. 39-54.

[7] A. Khalfaoui. (2012). Etude expérimentale de l'élimination de polluants organiques et inorganiques par adsorption sur des matériaux naturels : application aux peaux d'orange et de banane. Thèse de doctorat en génie des procédés, université Mentouri, Constantine, Algérie. pp. 180.

[8] M.J. Ahmed and S.K. Dhedan. (2012). Equilibrium isotherms and kinetic modeling of methylene blue adsorption on agricultural wastes-based activated carbons. Fluid Phase Equilibria. 317. pp. 9-14.

[9] D.B. Maazou, H.I. Hilma, M.M. Malam, Z. Adamou and I. Natateri (2017). Elimination du chrome par du charbon actif élaboré et caractérisé à partir de la coque de noyau de Balanite Aegyptiaca. International Journal of Biological and Chemical Sciences. 11(6). pp. 3050-3065.

[10] O.S. Mamane, A. Zanguina, I. Daou and I. Natadou. (2016) Préparation et caractérisation de charbon actif à base de coques de noyaux de balanites Egyptiaca et de Zizyphus Mauritiana. Journal de la société ouest-africaine de chimie. 41. pp. 59-67.

[11] D.O. Kra, N.A. Kouadio, G.P. Atheba, B. Coulibaly, N. Allou, K.G. Gbassi and A. Trokourey. (2015). Modélisation des propriétés adsorbantes de charbons activés issus de deux variétés d'acacia (auriculiformis et mangium). International journal of innovation and scientific research. 13. pp. 542-523.

[12] I. Tchakala, B.L. Moctar, G. Djaneye-Boundjou, K.S. Doni and P. Nambo. (2012). Optimisation du procédé de préparation des charbons actifs par voie chimique à partir des tourteaux de Karité et des tourteaux de Coton. International Journal of Biological and Chemical Sciences. 6(1). pp. 461-478.

[13] A. Touati (2010). Préparation d'un charbon actif par pyrolyse de la biomasse : cas du noyau du fruit du néflier. Mémoire de magister en génie des procédés, université Larbi Ben M’Hidi Oum El Boughi, Algérie. pp.141.

[14] K.A. Mayeko, P.N. Vesitulata, J.N. Phanzu, D.M. Muanda, I.B. Lopaka and M.J. Mulangala. (2012). Adsorption de la quinine bichlorhydrate sur un charbon actif peu couteux à base de bagasse de canne à sucre imprégnée de l'acide phosphorique. International Journal of Biological and Chemical Sciences. 6(3). pp. 1337-1359.

[15] F. Ibanez. (2002). Etude de la carbonization et de l'activation de végétaux durs et mous. Thèse de doctorat en science, université de Neuchâtel, Suisse. pp. 147.

[16] C.K. Balogoun, L.M. Bawa, S. Osseni and M. Aina. (2015) Préparation des charbons actifs par voie chimique à l'acide phosphorique à base de coque de noix de coco. International Journal of Biological and Chemical sciences. 9(1). pp. 563-580.

[17] B. Faouzia. (2014). Elimination des colorants cationiques par des charbons actifs synthétisés à partir des résidus de l'agriculture. Mémoire de magister en génie chimique, université Ferhat Abbas, Algérie. pp. 103.

[18] M.K.B. Gratuito, T. Panyathanmaporn and A. Dutta. (2008) Production of activated carbon from coconut shell: optimization using response surface methodology. Bioresour Technology. 99. pp. 4887-4895.

[19] B.S. Girgis and A-N.A. El-Hendawy. (2002). Porosity development in activated carbon obtained from date pits under chemical activation with phosphoric acid. micropor, mesopor mater. 52. pp. 105-117.

[20] N. Kouadio, D.O. Kra, G.P. Atheba, P. Drogui and A. Trokourey. (2017). Degré d'activation, surface spécifique et fonctions de 
surfaces de charbons actifs d'Acacia auriculaeformis et d'Acacia mangium. International Journal of Innovation and Applied Studies. 20(2). pp. 568-574

[21] P. Atheba, K.G. Gbassi, B. Dongui, F.S. Yolou and A. Troukourey. (2014). Etude de la porosité, de la surface spécifique et des fonctions de surface de charbons actifs préparés après carbonisation artisanale des coques de noix de coco. Les technologies de laboratoire. 34(8). pp. 126-136.

[22] A. Namane, A. Mekarzia, K. Benrachedi and A. Hellal. (2005). Determination of the adsorption capacity of activated carbon made from coffe grounds by chemical activation with $\mathrm{ZnCl}_{2}$ and $\mathrm{H}_{3} \mathrm{PO}_{4}$. Journal of hazardous materials. 119. pp. 189-194.

[23] T.D. Tra Bi. (2017). Adsorption sur du charbon actif issu de coque d'arachide de deux colorants textiles : jaune 11 et bleu 16. Mémoire de master en chimie de l'environnement, université Jean Lorougnon Guédé, Daloa, Côte d'Ivoire. pp. 63.

[24] K.N. Aboua, D.B. Soro, M. Diarra, K. Dibi, K.R. N'Guette and S.K. Traoré. (2018). Etude de l'adsorption du colorant ornage de méthyle sur charbons actifs en milieu aqueux : influence de la concentration et de l'agent chimique d'activation. Afrique science. 14(6). pp. 322-331.

[25] M.A. Salleh, D.K. Mahamoud, W.A. Karim and A. Idris. (2011). Cationic, anionic dye adsorption by agricultural solid waste. Comprehensive review desalination. 280. pp.1-13.

[26] R. Hazzaa and M. Hussein. (2015). Cationic dye removal by sugarcane bagasse activated carbon from aqueous solution. Global Nest Journal. 17. pp. 1-12. 